Nehaya Awida-Yehya

Higher Studies of Israel

\title{
THE PARADOXICAL REFUGE OF IDENTITY: THE SEARCH FOR PALESTINIAN IDENTITY IN BILINGUAL EDUCATION
}

\begin{abstract}
Awida-Yehya Nehaya, The Paradoxical Refuge of Identity: The Search for Palestinian Identity in Bilingual Education [Paradoksalny azyl tożsamości - poszukiwanie tożsamości palestyńskiej w edukacji dwujęzycznej]. Studia Edukacyjne nr 49, 2018, Poznań 2018, pp. 487-514. Adam Mickiewicz University Press. ISSN 1233-6688. DOI: 10.14746/se.2018.49.32
\end{abstract}

The research focuses on Arab parents who chose to send their children to the bilingual schools in Israel. The objective is to address the factors that led to the dropping out of Arab students from public education and their participation in alternative education. This research presents the problems of the Arab schools, both in terms of the quality of the instruction and the academic achievements. The main argument is that the goals of Arab education in Israel discuss the need to instill in the students the values of the State of Israel as a Jewish state, without referring to the fact that in this society there is an Arab minority with its own nationality and the right to be an integral part of this society. This ignoring of the needs of the Arab student caused a decline in the quality of the instruction and in the academic achievements of the Arab schools in Israel. As a result of the disappointment of the parents, especially the "intellectual" parents, in pedagogical and social terms and in terms of the students' personal-national identity, "alternative education" developed in Arab society and Arab students dropped out of public education. This research found a high degree of satisfaction with alternative education in general and bilingual education in particular in all areas and primarily in the formation of the Arab student's personal and national identity.

Key words: Arab minority in Israel, Arab education, national identity, Arab parents in Israel, Arab students, alternative education

\section{Introduction}

Educated Arab parents have high awareness on the one hand of the weakness of Arab education both in terms of the quality of the teaching and the Arab teachers and in terms of the achievements in the schools and on the other hand of the weakness and the neglect of Arab education of the perso- 
nal, social, and national identity of the Arab students who are educated in the public schools of the State of Israel. Many of these parents choose to send their children to learn in the alternative bilingual/binational school (the schools that belong to the Hand in Hand Association), from the recognition and concern about the quality of Arab education and their child's future. These parents had a traumatic, corrosive, and discriminatory experience in their academic experience in Israeli higher education, both in terms of the mastery of the Hebrew language and in terms of their national-identity awareness as Palestinian citizens of the State of Israel.

The objectives of Arab education in Israel discuss the need to instill in the student the values of the State of Israel as a Jewish state, without reference to the fact that in this society there is an Arab minority with its own nationality, with the right to be an integral part of this society. ${ }^{1}$ In the Jewish schools, there is great emphasis on the development of the national identity, the active belonging to the Jewish people, and the promotion of the Zionist aspirations, while barely granting the most minimal recognition to Arab history. Requests to phrase aims that recognize the Arab minority in the Jewish and democratic state were submitted by Arab intellectuals and were constantly rejected. ${ }^{2}$ Thus, in the present educational system in Israel it is impossible to form a core program common to Arabs and Jews, because the educational discourse in Israel, official and public, is built on the principle that we want to cultivate educational values based on the values of Israel as a Jewish and democratic state. ${ }^{3}$

Furthermore, Israeli legislation has not yet explicitly recognized the right of the Arab minority to influence education, not as a private right and not as a group right, despite the trend in the legal discourse to adjust the educational system to the multicultural reality. Lacking all legal and content arrangement that engages in Arab education, the law gives nearly total freedom of action to the Ministry of Education, which controls the Arab educational system in a centralized manner, on the level of both the school and the colleges for teacher training. ${ }^{4}$ The policy of the Ministry of Education has in essence neutralized the influence of the Arab public on the education of its children and has swept the Arab students into the general state educational system. In the Ministry of Education, a special department for the

${ }^{1}$ S. Bargouti, Israeli Educational Core Requires Fair Inclusion of the Arab Public, Multidisciplinary Thought in Humanistic Education, 2011, 6, p. 42-44. (Hebrew)

2 Ibidem.

${ }^{3}$ Ibidem.

${ }^{4}$ A.K. Agbaria, Y. Jabareen, Policy of Training Arab Teachers in Israel in the Mirror of the Right to Education: Issues of Governance as an Expression of Recognition of the National-Cultural Uniqueness, Pages - Journal for Study and Research in Education, 2015, Mofet Institute. (Hebrew) 
Arab educational system was established, subject to the instructions of the Ministry, without any autonomy, and until the year 1989 a Jewish manager was in charge. ${ }^{5}$ The only part of education actually in the hands of the Arab public is the Arabic language. ${ }^{6}$

According to Anderson ${ }^{7}$, nationalism is a product of territorial ideology. In other words, the territory is linked to the past, since it connects past to present and is helped by the past to define its areas. The desire to belong to a nation derives from the human need to belong to a framework that gives the individual confidence and protection and enables the state as an institution to reach objectives and defend its interests. ${ }^{8}$ Thus, the national identity is a product of the feeling of identification and belonging to a group. This process symbolizes shared awareness and recognition of the collective members, all of whom has the social identity. ${ }^{9}$ A national identity connects the individual to his past and to his community, empowers him, and gives him a sense of belonging and meaning. Thus, national narratives inculcate in members of the nation one version, partial, biased, and controversial, of the historical past. ${ }^{10}$

The Arab minority in Israel has the full right to demand a collective right to education. It is a native, lingual, religious, cultural, and national minority that has suffered and is still suffering from deprivation and discrimination as a group. ${ }^{11}$

On the one hand, the present research study will attempt to present in short the social-economic reality of the Arab minority in Israel and the policy of education encountered by the Arab parents and especially the educated ones. On the other hand, this research study will attempt to examine the degree of satisfaction of the Arab parents in the bilingual schools and the fulfillment of the needs of the Palestinian minority who are citizens of the State of Israel in terms of the Palestinian national identity in the Arab schools and in formal education.

${ }^{5}$ I. Saban, The Collective Rights of the Palestinian Arab Minority: What There Is, What There Isn't, and the Taboo, Studies in Law, 2002, 26, 1, p. 241-319. (Hebrew)

${ }^{6}$ K. Abu Asba, Arab Education in Israel: Dilemmas of a National Minority, 2007. (Hebrew)

7 J. Anderson (Ed.), The Rise of the Modern State, Brighton 1986.

${ }^{8}$ H.C. Kelman, Group Processes in the Resolution of International Conflicts: Experiences from the Israeli-Palestinian Case, American Psychologist, 1997. 52, p. 212-220.

${ }^{9}$ D. Bar-Tal, Shared Beliefs in a Society: Social Psychological Analysis, London 2000.

${ }_{10}$ Y. Ben Shemesh, Individuality and Post-Nationalism in the Kadan Affair: Response to Yosef Gavrian, Acts of Law, 2010, 3. (Hebrew)

${ }_{11}$ Abas, 2004, in Y. Jabareen, A.K. Agbaria, Education on Hold; Government Policy and Civil Initiatives for the Promotion of Arab Education in Israel, Haifa University 2010. (Hebrew) 


\section{Review of the Literature}

\section{Background: 1948 - Independence and Nakba}

The State of Israel was established in 1948, after a number of events that paved the way for its establishment. The State of Israel is a Jewish state in the sense that most of the citizens are Jewish (people), it serves as the nation state of the Jews (nation), and has a Jewish religious affiliation, which is expressed in the assimilation of parts of Jewish religious law into the state law. ${ }^{12}$ After the war and the establishment of the State of Israel (an event known also as the Palestinian Nakba), the Palestinian population, which was the majority until 1948, became a minority in the Jewish population. ${ }^{13}$ This minority remained living in the borders of the State of Israel. ${ }^{14}$ This minority is considered a minority in terms of nationality and language ${ }^{15}$, in which there is another division according to the religious definitions, or Muslims, Christians, and Druse. ${ }^{16}$

As a result, in Israel a distinction and a separation exist in many areas between citizens according to their national and cultural origin, including in the field of the engagement. In addition, in the State of Israel, which is defined as a multinational country, there is a situation in which the national affiliation is not uniform for all the national groups who live therein, and the same groups develop different patriotic connections. The citizenship in Israel is presented as joint and uniform for all the citizens, but it is possible to see from the professional literature that the universalism and uniformity are but outside camouflage for hierarchical cultural patterns and perceptions built into the citizenship itself. ${ }^{17}$

\section{The Palestinian Arab Minority as a Native Population}

In Israel of 2014 there are about 75\% Jews and about 20\% Arabs, but in most areas of life there is a considerable separation between the two groups. The absolute majority of Israeli lives in single-national communities, works in separate workplaces, and learns in separate institutions in the educational

12 U. Zilbersheid, The Legal-Political Development of the Declaration of Independence - Victory of the Perception of Bourgeoisie Democracy, Democratic Culture, 2009, 12, 7. (Hebrew)

${ }_{13}$ M. Al-Haj, Trouble of Employment among Arab Academics in Israel, [In:] Arab Academics in Israel: Main Characteristics, Potential of Graduates, and Situation, Ed. M. Al-Haj, The Jewish-Arab Center, Haifa University, 1988. (Hebrew)

14 I. Babiya, The Ethnic Transfer in Palestine, Beirut 2007. (Arabic); A. Ghanem, M. Mustafa, The Palestinians in Israel - The Policy of the Minority in the Ethnic State, Medar 2009. (Arabic)

15 S. Smooha, Measures of Jewish-Arab Relations in Israel, Haifa University 2004. (Hebrew)

16 B. Noyberger, Minorities and Democracy, [In:] Knowledge, Society, and Regime, Ministry of Education, Jerusalem 1995. (Hebrew)

17 A. Jamal, On the Patterns of the Establishment of the National Inequality in Israel, 2004. (Hebrew) 
system. However, the reality of separation is found in a process of change and in different areas more integrative spaces are created. ${ }^{18}$

The values of the State of Israel as a Jewish state make it unique from other democratic states. There are many democratic countries in the world, but only the State of Israel is a state that is not only democratic but also Jewish. This value, "Jewish state", leads to the conclusion that the values of the State of Israel, as a Jewish state, have two main aspects: the Zionist aspect and the Halachic ${ }^{19}$ aspect or the heritage aspect. ${ }^{20}$

The Arab minority has additional uniqueness, since it has a homeland. This is a native Palestinian Arab population, which lived in its homeland before the establishment of the State of Israel, when it was the majority group. ${ }^{21}$ This fact influences the struggle for the borders of the collective identity of both Jews and Arabs in Israeli society, a struggle related not only to the fact that Israel is a country of immigrants but also to its place in the Middle East and it emphasizes the issue of the complex relation between the Arab minority and the Jewish majority.22

The Palestinians in Israel are the only group in the modern history of the Arab nation that became a minority in its homeland, under a foreign regime identified with the West. They did not reach this status by choice or consent or international compact but by force of arms and following the Palestinian disaster, the Nakba. This historical fact becomes even more important since both the Jews and the Palestinians rejected the possibility that they would become a minority group in Israel. ${ }^{23}$

All these factors joined the feeling of the necessity to live in a society with a culture and nationality that defeated both the internal Arabs and the external Arabs, and therefore is considered an enemy of the Arabs in sweeping terms, at least until the Sadat initiative in 1977 and the Camp David Accord. ${ }^{24}$ Attempts at survival of the Arabs inside of the new state forced them to address issues relating to everyday coping. They refrained from engaging in the political context

18 U. Shwade et al., Integration of Arabs and Jews in the School in Israel, [In:] Report of the Situation of the State - Society, Economy, and Policy, Ed. D. Ben David, 2014. (Hebrew)

19 Halachic refers to Halacha, the body of traditional Jewish religious law.

20 A. Barak, The Values of the State of Israel as a Jewish and Democratic State, Multidisciplinary Thinking in Humanistic Education, 2011, 6. (Hebrew)

21 Y. Jabareen, On the Constitutional Status of the Arab Minority in Israel: New Motion, State and Society, 2010, 7(1), p. 105-139. (Hebrew)

22 Eisenstadt, 1989, in A. Ghanem, M. Levin-Rosales, Game of Identities: The Construction of Identity among Palestinian Women Citizens of Israel Who Studied in Schools in the Jewish Sector, Trends, 2015, 51, May. (Hebrew)

${ }_{23}$ Y. Jabareen, A. Agbaria, Autonomy for Arab Education in Israel. Rights and Possibilities, Knowledge Discovery, 2014, 5, Spring. (Hebrew)

${ }^{24} \mathrm{H}$. Koren, The Identity as Awareness: The Palestinians and the Arab Citizens of Israel - Between Unity and Uniqueness, National Security, 2009, 7, August. (Hebrew) 
of their issue and remained passive in the engagement with the problems of the region, despite the fact that they were directly and significantly influenced by the regional Israeli-Arab conflict. ${ }^{25}$

\section{Education, Identity, and the Palestinian Minority in Israel}

Noyberger ${ }^{26}$ notes the rights of ethnic minorities in a democratic state to maintain their language, heritage, culture, and nationality, through an official educational system in its language that enables a certain degree of autonomy for the purpose of intergenerational transfer or cultural contents to minorities, without the assimilation into the majority group. The formation of the national identity is important and meaningful for every citizen in any country, socially, politically, and culturally and especially for the minorities in the state. In Israel, there indeed is a system of elementary and high schools in Arabic for the Arabs of Israel. ${ }^{27}$

The status of the Arabs in Israel is a problem that derives from the national aspect and not as inequality. ${ }^{28}$ According to Smooha ${ }^{29}$, the struggle of the Arab citizens of Israel for civic and national equality appears in the eyes of the Jews as eroding the legitimacy of the state and as an expression of disloyalty. An attempt at such a national expression is perceived as a security risk that threatens the existence of the State and as an obstacle in the construction of the new Jewish state, whose neighbors have not recognized its existence. ${ }^{30}$

The educational system in Israel has never been perceived as a whole structure in which the Palestinian Arab factor constitutes a legitimate element. Although Israeli society is a pluralistic society, Israel intentionally has not created a common basis for true multicultural education and has missed an opportunity to expose Jewish students to Arab culture. ${ }^{31}$

The school has an important role in the definition of the identity. ${ }^{32}$ According to the perceptions of the identity that assume interaction between inter-

25 Ibidem.

26 B. Noyberger, Minorities and Democracy. (Hebrew)

27 Ibidem.

28 S. Barnea, Israeliness - Nationalism or Citizenship? Crisis and Anomaly in the Arab-Israeli Identity, [In:] New Directions: Journal for Issues of Zionism, Judaism, Policy, Society, and Culture, Ed. E. Ayal, 2011, 24, June. (Hebrew)

29 S. Smooha, Measures of Jewish-Arab Relations. (Hebrew)

${ }^{30}$ M. Amara, I. Saban, The Status of the Arabic Language in Israel: Law, Reality, and Boundaries of Use in Law to Change the Reality, State and Society, 2004, 4, p. 885-909. (Hebrew)

31 I. Abu Saad, Multicultural Education and the Palestinian Arab Minority in Israel: The Issue of Bedouin Arab Education in the Negev, [In:] Education in a Multicultural Society: Pluralism and Points of Encounter between Social Rifts, Ed. P. Pery, Carmel, Jerusalem 2007, p. 125-142. (Hebrew)

32 O. Aspachs-Bracons et al., Compulsory Language Educational Policies and Identity Formation, Journal of the European Economic Association, 2008, 6, 2-3, p. 434-444. 
nal and external processes, the school has a great potential of influence over the perception of the reality and the definition of the identity. Al-Haj ${ }^{33}$ found that the learning contents influence the identity. The Arab children in Israel learn in schools where the language of instruction is Arabic and not Hebrew and the curriculum includes chapters in the culture, heritage, history and religion of the Arab population. The studies of language and Arab literature are not always congruent to those of the schools in the Jewish sector. ${ }^{34}$ The separation in the educational systems is also preserved in the mixed cities, both in the language of instruction and in some of the curricula. Mixed schools in Israel are few. ${ }^{35}$

The State of Israel respects the right of the Arab population to have an educational system in Arabic, but the right to education in the mother tongue does not fulfill other rights of minorities in education, such as the right to have cultural-educational autonomy, so as to maintain and develop the cultural-natural heritage and identity. ${ }^{36}$ Although the State Education Law, 1953 defines the state educational system in Israel as well as the objectives of the system, it does so only in Jewish terms and for Jewish students. The collective educational interests of the Palestinian-Arab citizens in Israel are almost completely ignored in the language of the law. ${ }^{37}$

The educational policy of the State of Israel benefited the Arabs through the legislation of the Compulsory Education Law, which provided mandatory free education. However, the importance of the three fundamental principles of the country - a Jewish, democratic, and secure country - created contradictions in the policy that shaped the educational basis of the Arab minority. ${ }^{38}$ It is necessary to keep in mind that Arab education in Israel acts in the context of a country with a Jewish majority. This fact leaves the control in the hands of the majority group, while the minority group has a limited involvement in its contents. ${ }^{39}$

On the one hand, the State Education Law presents the main objectives of equality of opportunities for each and every boy and girl and the development according to their way and the creation of an atmosphere that encourages differences and support them, while on the other hand the law itself

${ }_{33}$ M. Al-Haj, Multiculturalism in Deeply Divided Societies: The Israeli case, International Journal of Intercultural Relations, 2002, 26(2), April, p. 169-183.

34 S. Tzartzur, Arab Education in the Jewish State, 1981. (Hebrew)

35 Y. Landau, The Arab Minority in Israel, 1967-1991, Am Oved 1993. (Hebrew)

36 Y. Rabin, The Right to Education, Li-On Sarigim, Nebo 2002. (Hebrew)

37 Y. Jabareen, Law and Education: Critical Perspectives on Arab Education in Israel, American Behavioral Scientist, 2006, 49(8), p. 1502-1074.

${ }^{38} \mathrm{~K}$. Abu Asba, The Dropping out of Students in the Arab Educational System in Israel: Description of the Situation and Suggestions for Treatment, 1999. (Hebrew)

39 K. Abu Asba, Arab Education in Israel: Dilemmas of a National Minority, 2007. (Hebrew) 
creates discrimination and harms the equality of opportunities for the Arab children, and this with the lack of the recognition of the Palestinian Arab identity. In addition, the law further focuses on the definition of the state as "Jewish and democratic", a definition that excludes the Arab population and discriminates against it both on the level of principle and on the level of practice. ${ }^{40}$ In essence, the Arab educational system is not defined in any section in the law, and hence the Arab educational system is devoid of conceptual and content existence in the Book of Laws. In this respect, it can be said that Arab education is absent-present in Israeli law. ${ }^{41}$

While the focus of the Hebrew educational system is Zionist and national, the Arab educational system lacks any Palestinian Arab content. The Arab educational system attempts to strengthen the cultural-religious component instead of the national-Arab component, from the perception that the Arabs of Israel constitute a security risk and embody the potential for instability. ${ }^{42}$

The objectives that encompass the educational system obligate the Arab students to learn about Jewish culture and values. The result is clearly seen in the state curriculum for the elementary and secondary schools: the Arab students are required to spend many hours learning about Jewish culture and history and learning the Hebrew language - more hours than they spend learning Arab literature and culture. In addition, they are required to develop identification with Jewish values and to promote the Zionist aspirations at the expense of the development of national awareness of their own and a sense of belonging to their people. The Arab national identity receives far less emphasis and the Palestinian identity does not receive any type of recognition. However, the primary objective of Jewish studies in the Arab educational system is not to develop cultural competence in the Jewish Israeli society but to force upon the Arabs to understand the Jewish/Zionist aims and to blur their national identity in Israel. Hence, it can be concluded that the general and specific goals of the curriculum developed for Arab education tend to blur, and not to strengthen, the creation of an Arab identity. ${ }^{43}$ The contents of the curriculum in the Arab schools deny the Palestinian-Arab identity and culture and emphasize the Jewish-Zionist values, thus naturally reinforcing

${ }^{40}$ D. Avnon, The Non-Democratic Aspect of the Basic Laws on the Topics of the Rights of Man, Politics, 1998, 2, p. 53-70. (Hebrew); Y. Jabareen, On the Constitutional Status of the Arab Minority in Israel, p. 105-139. (Hebrew)

${ }^{41}$ Y. Jabareen, A. Agbaria, Autonomy for Arab Education in Israel. (Hebrew)

${ }^{42}$ K. Abu Asba, The School Principal Is Subject to Great Pressures on the Part of the Clans, Another Country, 2005. (Hebrew); M. Al-Haj, Education among the Arabs in Israel: Control and Social Change, Jerusalem 1996. (Hebrew)

${ }_{43}$ M. Al-Haj, Education, Empowerment, and Control: The Case of the Arabs in Israel, Albany, New York 1995; S. Mari, Arab Education in Israel, Boulder, Syracuse 1978. 
the sense of deprivation of Arab students and teachers and causing a sense of steadily increasing alienation. ${ }^{44}$

According to Al-Haj ${ }^{45}$, the goal is to promote the goals of the political regime in Israel, primarily in all that pertains to the Palestinian identity and the loyalty of the Arab citizens to the State. The Arab educational system did not recognize the Palestinian identity of the Arab citizens and did not cultivate them as a national minority. In contrast, it aspired to cultivate an alternative identity disconnected from the historical, cultural, and national past.

In essence, the curriculum and the organizational structure of the Arab educational system in Israel place barriers to the shaping of the student's national identity. ${ }^{46}$ In contrast to the Jewish parallel, Arab education does not have educational goals for the development of belonging or national, cultural, or religious identity. ${ }^{47}$

The importance of the school for the student in the Arab sector is increased because of the lack of informal frameworks and institutions in Arab society. Thus, in relative terms, the Arab student spends considerable time in the school, which in turn influences his perception of identity, his attitudes, and his outlook. ${ }^{48}$

The issue of autonomy for Arab education challenges the hegemony of the majority group in Israel. ${ }^{49}$ The overall control by the Jewish educational system of the Arab educational system denies the Arab population the right to determine its educational objectives and to design the educational system according to its collective interests, and sabotages any significant involvement of Palestinian Arab educators in the process of the making of decisions, both regarding the budgets and regarding the educational contents intended for the Arab students. ${ }^{50}$ Thus, the Palestinian Arab collective educational interests suffer from the nearly absolute ignoring of the language of the State Education Law ${ }^{51}$, the lack of resources, and the lack of the ability to wield real influence. ${ }^{52}$

${ }^{44}$ K. Abu Asba, Between Tolerance and Threat, Facets: Journal for Culture, Society, and Education, 2004, 29, p. 48-50. (Hebrew); D. Golan-Agnon, Why Are the Arab Students in Israel Discriminated Against? [In:] Inequality in Education, Ed. D. Golan-Agnon, Babel, Tel Aviv 2004. (Hebrew)

${ }^{45}$ M. Al-Haj, Arab Educational System in Israel: Issues and Trends, Jerusalem 1994. (Hebrew)

${ }^{46} \mathrm{~K}$. Abu Asba, Attitudes of Different Factors in Arab Society on the Question of an Alternative Structure for the Arab Educational System in Israel: Summative Report, Israel: Follow-up after Issues of Arab Education in Israel, Gat: Masser 2003. (Hebrew)

${ }^{47}$ H. Pinson, D. Anon (Eds.), Citizenship, Civil Society, and Education: The Israeli Case in the Mirror of Western Democracies, [In:] The Language of the Citizen in Israel, Jerusalem 2006. (Hebrew)

${ }^{48}$ N. Hatav, The Future Orientation of Youths in Arab Society in Israel: Characteristics and Factors, M.A. Thesis, Jerusalem 1988. (Hebrew)

49 J. Bruner. Y. Peled, Rawls on Respect and Self-Respect: An Israeli Perspective, Political Studies, 1996, 44(2), June, p. 287-302.

50 I. Saban, The Collective Rights of the Palestinian Arab Minority, p. 241-319. (Hebrew)

51 Y. Jabareen, Law and Education, p. 1502-1074.

52 I. Saban, The Collective Rights of the Palestinian Arab Minority, p. 241-319. (Hebrew) 
Consequently, this policy of the Israeli educational system regarding Arab education led to the development of alternative national education in the Arab public, as a type of 'refuge' from the public Arab schools to the private schools, so as to obtain what they expect for their child, in terms of the quality of the teaching for access to higher education, personal empowerment, and formation of his personal and national identity. The irony is that Arab parents choose binational education over Arab single national education to fulfill their expectations.

\section{Bilingual Education}

Naturally, the geopolitical environment in which the school operates dictates the constant engagement in questions of identity, nationality, and citizenship. This engagement influences the parents whose children learn in the shared educational frameworks. ${ }^{53}$ Bilingual education and cooperation help eliminate relations of control that exist between the different sides, when this activity enables us to aspire to eliminate the separate existence of the two groups who are partners in the process and sets the school as an alternative model, both in the educational dimension and in the political dimension. ${ }^{54}$

The models of bilingual schools are different in their goals, student characteristics, continuity and amount of teaching in the different languages, methodological approaches, and amount and support of the decision makers and the community. ${ }^{55}$ Bilingual education is influenced by the philosophy and politics of the country or society to which this education belongs. Bilingual education not only reflects the decisions related to the curriculum but also is linked directly to the perceptions on the languages of minorities, their cultures, emigrants, the issue of equality in the state, the rights of the individual and the group, assimilation and integration, separation and discrimination, pluralism, and multiculturalism.

The framework of bilingual education is different in definition and nature from that of one-time meetings held from time to time under the title of 'coexistence meetings'. The shared educational framework is held on a daily basis and sets the idea of unity, which goes beyond the 'binational' division understood in the meetings of the first type. ${ }^{56}$ Bilingual pedagogy in the school seeks to promote the two languages and the history and culture of the two

${ }^{53}$ U. Adiv et al., National Perception, Shared Activity, and Bilingual Education: The Case of the Galil School, Discovery: Multidisciplinary Journal for Education, Society, and Culture, 2013, January. (Hebrew)

${ }^{54}$ Ibidem.

55 C. Baker, European Models of Bilingual Education, 1993.

${ }^{56}$ U. Adiv et al., National Perception, Shared Activity. 
partner populations. ${ }^{57}$ The geopolitical environment in which the school operates dictates to it and its environment the constant engagement in questions of identity and citizenship..$^{58}$

Different researchers have shown that bilingual education succeeds in the implementation of its goals, both on the high level of bilingualism, equal opportunity for academic achievements, and strong and positive multicultural identity that includes positive attitudes towards the other person ${ }^{59} \mathrm{Ho}-$ wever, bilingual education through immersion, which came from Canada, is most successful, and its objectives were speaking, reading, and writing in both learned languages, to teach and to evaluate the customs and culture of both partner nations. ${ }^{60}$

The Hand in Hand Association was established in Israel in 1997, with the goal of promoting and developing a shared society for Arabs and Jews. For this purpose, the Association establishes and operates an infrastructure of educational and social frameworks for the shared life of the country's citizens. The curriculum of the Hand in Hand schools is based on principles that reflect the two cultures and the two languages, without preference for one of them, and on education for multicultural literacy and shared and equal citizenship. The Hebrew and Arabic languages have equal status in the school, and the children learn together, in both languages. In addition to the core studies mandated by law, the holidays and special days are celebrated in the schools on the different calendar dates. All the schools are recognized and official, under the supervision of the Ministry of Education. The Hand in Hand Association has a forum of school principals and a regular forum of teachers, all of whom work on the school curriculum. In addition to the educational frameworks, the Hand in Hand Association operates community frameworks for adults. This activity is intended for the students' parents, the teaching staff, and interested civilians, who together establish a shard community space. Since 1998, the Hand in Hand Association has established three schools, in Misgav, Jerusalem, and Kfar Kara. In 2012 a bilingual kindergarten was established in Haifa, and in 2013 in Yaffo. From September 2015 the graduates can learn in two bilingual first grades established in Yaffo. Most recently, another kindergarten was established in the Beyt Berl College area. ${ }^{61}$

${ }^{57}$ A. Mor-Sommerfeld, F. Azaiza, R. Hertz-Lazarowitz, Into the Future: Towards Bilingual Education in Israel, Education, Citizenship, and Social Justice, 2007, 2(1), p. 5-22.

${ }^{58}$ Z. Bekerman, N. Shhadi, Palestinian Jewish Bilingual Education in Israel: Its Influence on School Students, Journal of Multilingual and Multicultural Development, 2003, 24(6), p. 473-484; A. Mor-Sommerfeld, F. Azaiza, R. Hertz-Lazarowitz, Into the Future, p. 5-22.

${ }^{59} \mathrm{~J}$. Crawford, Best Evidence: Research Foundations of the Bilingual Education Act, National Clearinghouse for Bilingual Education, Washington DC: 1997.

${ }^{60} \mathrm{M}$. Amara, The Model of Bilingualism of Hand In Hand, The Center for Jewish Arab Education in Israel, 2005. (Hebrew)

${ }^{61}$ Hand In Hand Association Website (n.d.). http:/ / www.handinhandk12.org/ 


\section{Methodology}

The research study is a qualitative study.

\section{Research Question}

According to the review of the literature, for the most part there is no answer to the formation of Palestinian national identity for the Arab students in Israel in the state Arab schools. Thus, the research questions are: How do Arab society and especially the Arab parents cope with this miserable situation and what are the alternatives/solutions, if they exist, that the Palestinian minority citizens of the State of Israel have adopted? Do these alternatives/solutions meet expectations and needs, and if so were they accompanied by suspicions, concerns, and dilemmas?

\section{Research Objectives}

The main objective of this work is to examine the factors of the search of the educated Arab parents for alternative schools and their satisfaction with these schools and the fulfillment of the instructional and value expectations of these schools in the eyes of the educated parents. The applied objectives are to interview the Palestinian parents who are citizens of the State of Israel and who have chosen to send their children to bilingual and binational private education of the Hand in Hand Association and the reasons and causes that compelled them to make this choice and their satisfaction with the quality of education in it.

\section{Research Population and Respondents}

The present research study was conducted in the three schools of the Hand in Hand Association that offer bilingual/binational education. In Israel there are only three bilingual schools (not including kindergartens): the Bridge over the Wadi School in Kfar Kara, the Galil Elementary School in Misgav, and the Max Rayne School in Jerusalem. The Bridge over the Wadi School and the Galil School are elementary schools, while the Max Rayne School is both an elementary and secondary school (having classes from the kindergarten through the twelfth grade). All in all, three parents from each school participated in the research, for a total of nine parent interviewees.

The parents are Palestinian citizens of the State of Israel whose children learn in bilingual/binational education. Three parents are from Kfar Kara and belong to the Bridge over the Wadi School. Two parents are from Sakhnin, and one is from Kfar Shaab and they belong to the Galil School. Three parents from the North who live in Jerusalem belong to the Max Rayne School in Jerusalem. The interviews with the parents are numbered from 1 to 9 , so as to maintain the anonymity of the respondents. 


\section{Research Instruments}

The instruments for the collection of the data are qualitative instruments. They included semi-structured interviews with the parents who sent their children to the bilingual schools. In this type of interview, the phrasing of the main question is undertaken ahead of time, but the continuity of the presentation is not determined ahead of time and there is room during the interview to add questions according to the context, when sometimes the interviewee's questions lead to spontaneous answers. The goal of the interviews is to examine attitudes and opinions towards the bilingual schools and the teaching therein, as well as the influence of the school on the parents and their children. In addition, we set the goal of learning about the parents' perception of the school effectiveness, their satisfaction with it and its performance, and their evaluation from their perspective of the degree of the school's success in the achievement of its goals.

\section{Data Collection}

After the researcher obtained approval of the Manager of the Department of Education of the Hand in Hand Association and of the different school principals, the researcher was given the details of the coordinator of the graduates. Through the coordinators, the researcher obtained the graduates' phone numbers and after the graduates' parents consented to the interviews, the interviews were coordinated.

The research study focuses on the parents who sent their children to the bilingual schools from the three schools (Jerusalem, Galil, and Kfar Kara). For the purpose of this research study, segments were taken from the interviews, when these passages meet the theme/main topic of this article - the factors that led the parents to send their child to the bilingual school, sharing the dilemma and their traumatic experience as educated parents in the institutions of Israeli higher education, and their satisfaction with bilingual education. The interviews were conducted from February 2016 to September 2017. The parents were interviewed, most via the telephone and some face to face. It was very difficult to succeed in setting a time and date for the interview, since the parents were busy with work and home. Consequently, the researcher was forced to hold telephone interviews since suitable times could barely be coordinated between the researcher and the respondents. The interviews were held in places in the home, at work, in the cafeteria, or by phone with the parents. The interviews were all recorded and transcribed at a later date.

\section{Data Analysis}

The analysis of qualitative data is a process of the arrangement and structuring of the information collected for the purpose of the interpretation and understanding of its meanings. The method of analysis adopted in the present 
research study is the topic method. In this method, use is made of passages of text (and not words or single expressions). The products of the analysis are topic categories - themes. According to the research questions, the interviews were analyzed and main categories were identified that address the implementation of the program. These will be presented in the chapter of the findings.

\section{Research Findings}

This chapter will present the findings of the research studies according to the research questions. The findings focus on the data learned from the interviews with the parents and bring the factors and deliberations that accompany the decision to send their children to bilingual schools and the degree of satisfaction with the fulfillment of their expectations.

\section{Causes and Personal Experience that Led the Arab Parents to Send their Children to the Bilingual School}

In the parents" response to the questions of "what are the factors and causes of sending your child to the alternative school and not the public school?", all the interviewees from all the schools answered that the Arab public schools are very disappointing in their quality of teaching and in the failure to form the student's personality and to provide a response to his needs in many regards - values, formation of personal identity, formation of national identity. This is seen clearly in the argument of one of the parents when he compared between the bilingual school and the regular Arab school, "... since I sent my children to this school ... to form the personality ... since I am very disappointed with the public schools ... since they do not function appropriately in all areas ... behavior, value, education, achievement. ... there is no reference to the student's personality or the look at the student's thinking ... or the thinking outside of the box ... even in pedagogical and achievement terms ...it was not on the highest level ... but also the rest ... but in social terms ... every public school does not provide the necessary service ... the intention ... the building of the student's personality so that he can cope with ... (speak Arabic or Hebrew) ... form a personality that will cope with the everyday and social problems in Israel ... in addition, the professionalism/training of the regular schools in which there isn't anything ..."

A different parent continued and added a reason: "The reason is that the teaching method is completely different from here ... it lets the student express ... say that he wants ... to say ... work on the principle of comprehension ... more than repetition ... this is the point regarding the teaching, regarding the 
relations ... unfortunately, here (bilingual school) there is respect, not like the school where there is violence, where there are beatings..."

In addition, many of the interviewees asserted that the Arab schools do not look at the student as a person who has an opinion and special needs but as a 'grade factory'. One of the parents maintained that the competition for achievements is one of the main reasons why they fled from the public Arab schools. "For many reasons, I in my work ... visited many Arab schools, and from my education and what I experienced in my childhood in the Arab schools, most look only at the grades, and the person who learns faster, there is even competition between the families whose child has the best grades ... and in my opinion this method of teaching ... on my part there should be especially in elementary schools enjoyment and fund and activities and also to learn, but without pressures. 'How much did you manage to learn today?' ... But when I went to see how they teach in this school I saw something different, I saw that they work on the student's personality, the discovery of his abilities and talents that they attempt to develop and promote in the process of the studies, and this is the power that attracted me to register my children to this school ... since there are also no tests."

Another parent continued and compared nicely the difference in the feeling of his daughter between the regular Arab school and the bilingual school: like being in a greenhouse and then going out into the cold and emptiness. "In the Arab schools the emphasis is on achievement ... only the grades are important ... it is true that the grades are important but the 'formation' of the student's personality ... the self-confidence, for him to be creative and thinking and all those ... for the 'daughter' ... in other words, she acquired all of them ... she certainly saw the gap and the emptiness (coldness), it is great, like going from hot water and tossing into cold water."

Therefore, most of the Arab parents search for a school framework for their child that will be enjoyable, experiential, without fears of achievements and self-esteem. It is possible to hear this in the quote. "I want my children to learn from love of learning and reading, also not to give them much homework. The problem is that the Arab schools give so much homework it is exhausting."

As a result of the reasons and causes mentioned previously, the findings in the continuation of the interviews with the parents indicate that one of the reasons why the Arab schools do not engage in value-oriented, national, and identity issues of the Arab student is the fear of the establishment. "... But in principle a private or public school is 'limited' by and 'dependent' on the government in political terms, and the principals of the private schools with us definitely greatly support and are interested in 'satisfying' the establishment and the budgets will not come from the State ... therefore the schools among 
us search for more 'excellence'. More in the field, and therefore for them personally the student, his heritage, his national awareness develops with the parents, and they are not connected to one another, and it is not supposed to happen with them ..."

Another parent shares a finding with proof of this fear, which is not unfounded, and it does exist, with justification, in his assertion. "... First, they have fear ... second, the Ministry of Education always or the supervisor always attempts to prevent these things (establishment of ceremonies for national days), does not like and does not encourage it.... Do you understand ... once, for instance, in the high school here in the village they attempted to do activity on 'Land Day' ... outside factors came and sought the permission to establish a ceremony for Land Day ... and we did this ceremony in the school building ... then the principal was summoned for a discipline investigation by the Ministry of Education about how he does such things ... in other words, the fears among us are justified and real."

As a result of the fear of the public Arab schools to discuss and to develop the personal and national identity, educated Arab parents prefer alternative education over public education. For instance, one parent asserted that he sent all his children to the bilingual school, primarily because of the clear and stable and orderly engagement in all that is related to heritage, events, and national days of the Palestinian Arab society in Israel, which the Arab schools are afraid of addressing.

The national events and days of Palestinian Arab society in Israel, which Arab public schools are afraid of addressing, "have topics that speak about the Nakba, about the independence, about Land Day ... you know our school (the Arabs) have fear both on the part of the teachers and on the part of the principals, from the Ministry of Education."

The policy of intimidation, as it was defined by one of the parents, is entrenched until today in the heart of the teachers and the older generation, who convey it to the students. When a parent is tired of this fear and looks for a change, it is seen in his statement. "We were in the parents' conference ... and the homeroom teacher comes to tell us the same thing 'if he has a black mark, then he cannot learn ... (if the establishment gives him a black mark)... and here I stopped the homeroom teacher and said ... till here, stop, every person can educate his son as he wants' ... you, your role is to give us the contract ... and I don't need you to give us your opinion ... this policy of intimidation ... it is forbidden to us to instill in us this fear, that this will be conveyed to our children and this will be conveyed to the descendants. It is forbidden to us to be afraid of this policy of intimidation ... thus we will never advance ... I always hope that there will be an age and generation with awa- 
reness and with thinking ... that the coming generation will make the change ... since our role is to educate, to encourage, to push ..."

A very important finding that arose from the findings is the parents' personal experience. Most of the interviewees shared that their personal traumatic experience, both in the school and in the institutions of higher education, was one of the main factors that caused them to search for an alternative framework for their child, other than the standard Arab public school, which does not provide the 'merchandise' as necessary, both in terms of the Hebrew language, self-confidence, proud and positive self-view of their personal and scholastic ability, learning skills, and most importantly the ability to cope with difficulties.

"First, my personal experience began when I was a student in the Hebrew University, when I was at that time eighteen years old, for me the encounter/ exposure with the other side, the Jewish side, was almost the first, in other words, this is the first time that I am in friction with you in a serious, direct, and long manner, I felt that I am a second class citizen. ... I felt racism and discrimination as an Arab student from the lecturers and from the students, and this was very difficult for me, or in other words, my experience for four years in Jerusalem when I really hated Jews since I felt weak and truly second class ... therefore, my experience caused me to think that I do not want my children in it ... do not want my children to feel they are second class or weak or that the Jews in front of us are more cultured or better than us ... rather, the reverse, I want that they will live and will see and will know and will be in contact with them, this is one thing. Second thing, it is important to me that they will be equal in rights ... and that the Jewish student will know that the Arab student is not a monkey or ... that he knows he is a person, that he has a culture and a heritage ... and we are not less than them ... this is what is important to know about one another ..."

On the importance of the exposure to and knowledge of one another, another parent continued and talked about his personal experience as a student. "I personally experienced when I began to study in the university ... how great the gap between us and the Jews is, in thoughts, in knowledge, when I was in the university ... I was 19 years old ... they are strange to me and I am strange to them ... and every side has its stereotypes about the other side ... and is closed in it ... I did not like it and I did not want that my children would experience this difficulty ..."

To differentiate, the childhood experience of another parent, following the feeling of inability/paralysis in communicating with Jews in general and in the Hebrew language in particular, is one of the main factors of sending their child to the bilingual school. "I remember when I was little I had a great problem how to communicate with Jews in language and in values, I did not 
understand their opinions, their thoughts ... even ... I did not know how to speak with them ... I saw that this is a good step to give my children what I thought that would be worthwhile for me ... if I had." "Therefore, I see today that I must let my children know these people and this society ... and for good ... so as to achieve something more believable in Arab society ..."

As a result of the traumatic experience presented previously of the Arab parents themselves, they asserted that they are interested in their child knowing and being exposed to another culture. On the one hand, it is important since he lives with them in the same country, but on the other hand it was important for the educated Arab parents for their child to also know and recognize his own heritage and culture and be proud in it, to know he is not less than the 'hegemonic' Jewish student but he too has a heritage, history, and culture.

This finding can be seen in the following statement. "The combined learning of the two languages and two nationalities was important to me since we Arabs grew up in villages and do not have contact with Jews and we also grew up with the fact that they are the rulers, they are the strong ones, and they go to the military ... and we always had a fear of them ... and always we had the feeling that they are stronger and better and wiser than us."

Another parent added to the argument above. "This problem ... is I am like him, he is like me, and he is no better than me ... perhaps I am better than him ... and I personally have experienced a difficult experience ... in the first year to the point of depression (in the university) ... I do not want my children to be such ... and how I will do this, already from a young age ... that you are not less ... and perhaps you are more than him ..."

The Arab parents who live in the Northern region (Kfar Kara and Sakhnin) to send their children to bilingual education and the parents who 'live' in Jerusalem are different in their reasons and causes for the choice of the bilingual school for their children. It becomes clear that most of the parents in Jerusalem who send their children to the alternative/bilingual school are originally from the North, and they came to Jerusalem in pursuit of their higher education and continued to live there. They maintain that they suffer from 'lack of options' and from no choice in the selection of the Jerusalem public schools. The residents of the city of Jerusalem are 'residents' who learn according to the Palestinian format that does not correspond to the Israeli format and its core subjects and primarily does not teach the Hebrew language. Moreover, the Jerusalem educational system suffers from far lower quality and teaching services. In comparison, the Arabs who are citizens of the State of Israel must learn according to the Israeli format and take the high school matriculation certificate and learn the Hebrew language. It is possible to see the reasons for sending their child to the bilingual school in the saying of one 
of the parents that they are originally from the north and live in Jerusalem, in the differences between Jerusalem education and Israeli education, and even in the differences in the life routine of both regions.

"But here...I do not have another good option...here in Jerusalem I do not have any options... here there is no possibility of choosing or making a comparison between the north, and the study in the north and the study here in Jerusalem...since here...the scholastic situation and the quality of the teaching here in Jerusalem are terrible ... and did not give me the possibility of choosing.... and the bilingual school is very very good, in terms of both the teaching, the culture...education....and the independence of the student...the self-confidence of the student..."

The parent continued about the differences between the two regions. "Many things are different ... it was very hard for me to adjust to them ... therefore, when I registered my son to the school, even education in the 'Beyt Safafa' school, it is different from us ... we will open a bilingual school ... where Arab and Jewish children are taught ... many of the Arabs ... most of them are from the North ... this was very suited for me."

Another assertion was mentioned during the interviews on the causes of sending the child to the bilingual school, deriving not only from the differences between the Palestinian educational system and the Israeli one but also from the tense life routine in Jerusalem. The Arab parents stated that the importance of the knowing of the Hebrew language is vital and is a way of coping for their child in cases of danger, since not knowing the Hebrew language is a cause of concern. "So that they will get along since if she knows the language (Hebrew) she will get along in everything ...you will not have a problem, and things will flow since the language is very very important ... I see here ... from my work in the eastern part of the city here ... educated people ... of a high level. They have certificates and high roles but when they come to ask something from the department ... how much this person has education, culture, and knowledge ... if he has a problem with the language ... he cannot express himself ... then I need to leave my office to understand from him something in Arabic what is his problem/request ... to help him... he does not know how to read and write in Hebrew ... although he is a person with an important role in his village ... look, he has a prestigious social position in his village but look ... he does not know how to express himself and does not know to say what he wants...since he did not learn the Hebrew language...such things...caused me to think about my children...I don't want them to have this problem...I want them to get along ... so that they can cope with life here in Jerusalem, since life is hard here especially in the recent period."

To conclude, it seems that most of the Arab parents who chose to send their children to the bilingual school come because of their disappointment with 
the public Arab schools and following their own difficult experience, primarily in the institutions of higher education, where they felt weak in many respects, both in terms of the language and in their view of themselves as weak and not as good. All this caused them to think and search for their children for a framework that would provide all that was missing for them, in the Hebrew language, in the encounters with others, in the learning skills, and in most importantly the 'acknowledgement' of their heritage and identity, in a proud and positive manner, without the fears found in the Arab public schools in Israel. We call this 'corrective compensation'.

\section{Dilemma of Arab Parents Who Sent Their Children to the Bilingual School}

Most of the Arab parents maintained that at the beginning of the learning of their children in the bilingual school, they received sharp criticism, negative, frightening, and deterring, about the future their children could expect. The main caution and criticism were on the issue of values, culture, and norms of Arab society in contrast to Jewish society.

The findings indicate that the deterrence and intimidation about sending their children to the Jewish school was directed especially when there was a 'daughter', as if this is a great disaster. This can be seen from the statement of one of the parents in the deliberation about the warnings encountered at the beginning of the path of the registration of his daughter to the bilingual school. "Then there was very great criticism...you are exposing your daughter to a culture different from ours... perhaps they will be influenced by it and will change... and will be impolite and insolent."

Another parent added on the argument that there was criticism directed to the sending of their children to the bilingual school. "Many began to scare me and to tell me that tomorrow your girls will love a Jew and will begin to dress, I don't know what ..."

The findings indicate the cost of sending a daughter is higher than the cost of sending a son. This can be heard in the statement of one of the parents at the start of the path. "When they would ask me where I registered my children to, I would hear negative criticism. Why are you sending them to learn with Jews, do you want your children to be like the Jews? You're lucky you don't have girls, since I only have boys. When I asked why, they would answer since if you had a girl she would dress like Jewish girls...they said that they would be influenced by them and would be insolent like Jewish children and would dress differently...they would be impolite to their parents."

Another dilemma revealed during the interviews at the beginning to the Arab parents is that their child would forget his identity, culture, and heritage. It was even 'expected' or 'predicted' that the child in the future would betray 
his nation and would cooperate with the State of Israel. This can be seen in the parents' statements. "You are sending them to learn about Jewish culture ... and thus they will be alienated and will be distant from their identity...it is as if you want to make them into collaborators ... who will be distant from their social culture... be like all the Jews...he will have a Jewish girlfriend. His girlfriend will not come to the home... all this." Another parent who encountered deterrence at the beginning added that, "...many began to frighten me...it's as if they told me that my son and daughter would be Israelized, and they would take all the Jewish norms and values and forget their culture/heritage and forget their identity and forget everything."

In addition, a considerable number of the parents argued that they received 'cautionary' criticism about the quality of the teaching and achievements of the bilingual school. One of the parents shared criticism directed to him at the start. "There was criticism from all sides, from my family and from my wife's family. They claimed that this school ... beginning from they don't learn anything ... their achievements are not so sure ... this is an unrecognized school..."

A minor dilemma revealed during the interviews among the Arab parents is about the learning of the Islamic religion and the Arabic language. For instance, one of the parents shared the deliberation and dilemma of the spouse, who objected to sending their son to learn in the bilingual school, since it was argued at that time that "... My son would take on their values ... the behavior of the Jews ... the norms of the Jews ... would be like the Jews ... would forget the Islamic religion and would forget the language ... would forget and forget."

To sum up, it can be seen that most of the Arab parents who decided to send their children to the bilingual school encountered sharp criticism, cautionary and deterrent, about the 'miserable' future of their children. The main focus of the deterrence was that their children would adopt the values and norms of Jewish culture and especially that the Arab girls would adopt the clothing of the Jewish girls. Another deterring dilemma that was brought up before the Arab parents was that their children would forget the national identity and Arab heritage and would be Israelis in all respects. The concerns that the children would forget the Islamic religion and that the level of achievement would be low were also mentioned, but only slightly.

\section{Degree of Satisfaction with the 'Product' of Bilingual Education}

The degree of satisfaction of the Arab parents was measured according to a number of parameters, such as quality of teaching, quality of formation of the student's personality, and quality of the formation of the national and religious identity. The parents are highly satisfied with the formation of the 
personality and the national identity. However, there were differences of opinion regarding the quality of the teaching and the degree of the studies of the Islamic religion of the Arab student in the bilingual school.

Satisfaction with the Formation of the Student's Personality. First I present the satisfaction of the Arab parents, opening with one of the nicest statements, which characterizes the warm atmosphere of the bilingual school. "You feel the school is a small village and everybody knows everybody both about the students and about the teachers, There are good relations between them. This gives the student the possibility of feeling the tranquility and the ability to draw close and this strengthens the student's personality."

Then we continue, asserting that it was found that parents are satisfied with the degree of formation of their child's personality in the school, which is clearly seen when one parent was asked to compare the personality of his daughter who learned in the bilingual school to his other children who learned in the Arab public school. He presented the differences, "I tell you what is the difference between my daughters, they are all strong, but the difference is that she (the bilingual school student) appreciates herself, she is stronger, in other words, she can cope with the challenges and difficulties in life and even in the studies in the university...without concerns or fears."

Most of the parents maintained in the continuation of the interviews, in the transition of their child from the bilingual elementary school to the Arab public school in their village (the Galil school and the Bridge over the Wadi School are only elementary schools) that their child's personality was prominently praised by the teachers who teach them. "Until today they ask in the school what was the 'secret recipe' that these children take from the bilingual school, they come with this personality and they know to speak and to express and their language is good, in Arabic, in Hebrew, and in English. They speak seriously and they have great self-confidence...with limits."

Satisfaction with the Formation of the National and Religious Identity. The parents are satisfied with the degree of the formation of their children's national identity, when most of them asserted that in the bilingual school they did well what the public Arab schools did not do: the preservation of the heritage, history, and the national days that are important to Arab society in Israel, such as Land day, the Nakba, the abandoned villages, and so on. For instance, one of the parents said: " ... in the school, they address the national days and the religious holidays, like Land Day, for instance ${ }_{\text {,I, }}$ or when there are strikes in the schools and how they cope with this in an educational and academic manner ... in other words, there are topics in which they talk about the Nakba, about independence, and about Land Day ... you know in our 
schools (the Arab schools) there is the fear on the part of the teachers and the principals of the Ministry of Education ... so they knew that this school reinforces the student's personality and maintains his heritage ... his national identity ... this is not only co-existence and we are together like the Israelis or the Jews and thus the reverse preserve our values and norms."

Another parent adds that ironically the bilingual school does better in teaching the national days and heritage, and even the Islamic religion, than do public Arab schools. "Regarding the national days for the Jews and the Arabs...the school I think it was preferable and better in this regard than the Arab schools in Sakhnin...even for the religious days ... I remember once there was a birthday for the Prophet Mohamed and in the school there was a ceremony ... and the next day I asked my nephew (not in the bilingual school) and I asked him why there was no school today ... my nephew answered me that he does not know why there is no school ... he did not know that it was because it was the birthday of the Prophet Mohammed, in parallel in the --school there was a ceremony especially ... I am very very satisfied with what the school gives in the national days."

There were differences of opinion regarding the degree of satisfaction with the studies of the Islamic religion. Most asserted that the ceremonies/ holidays important in Islam were conveyed but not in real depth. Therefore, one parent said that he had to assume the responsibility to fill in what was missing at home in the studies of the Islamic religion. "...He was taught in school about the Islamic religion ... but I continued at home ... what he was missing I gave him ..."

In terms of the quality of the teaching and the achievements, there were clear differences of opinion about the quality of the teaching. Some of the parents maintained that the quality of the teaching was very good. "I am very very satisfied in terms of the teaching and in terms of the informal education, the formation of the personality ... in terms of the teaching this is correct ... it is not necessary to give him instruction in learning by rote ... but they work more on the understanding, they give him tasks of search and inquiry ... and home ... they give the child his contentment in which he can collect information ... there is a border for everything ... it is not 'borderless' $\ldots$ but the student is allowed to search ... and to clarify from the parents ... once they had a task and they went to ask their grandfather."

Unlike this parent, another parent maintained that the quality of the teaching slightly concerned him at the start. "... and in pedagogical terms ... in terms of achievement ... there was no infrastructure in scientific terms ... as a father I had ... I do not remember why I said to learn material ... I remember that in the first year he did not know to read and I waited to the following year ... in terms of achievement it was not so prominent or important ... even 
the report cards, they are not report cards of grades but certificates of assessment... for instance Arabic, the assessment is how he reads words and so on ... or how much he can solve in mathematics ... this is not a report card to present to the neighborhood or to society ... like other parents, Arab society is also ... the mother takes the report card to show off ... you know what I am talking about ... this is not something that I am 'imagining' ... the report card is not to show off ... but what he is and what his abilities are ... and how it is possible to improve...."

An important finding that can explain the criticism of the quality of the teaching in one of the parents' arguments is that " ... some of the teachers, in my opinion, are not suitable ... this is professionally, in terms of personality they are all excellent ... some of them professionally are supposed to improve or to take an in-service training course ... and the curricula, in my opinion they ... the hand in Hand Association is responsible for the building of the curricula ... and I as a father am satisfied with the curricula, it is diverse, it has different topics, the students are really benefiting from it ... and they also realize some of their desires and inclinations, especially with the recent extracurricular courses they offered ... in general ... I ask and clarify with my children about the school ... I feel that the children are really happy ... they go gladly to school and do not need to be forced ... they are very serious, and energetic."

To sum up, most of the Arab parents are satisfied with the work and atmosphere of the bilingual school. All admit the school has a positive influence on the formation of their child's personality and national identity, but in parallel there are differences of opinions about the quality of the teaching and the teachers who teach and about the right to learn Islamic religion studies.

\section{Conclusion}

Most researchers have found that the situation of the Arab educational system in Israel is poor, suffering from lack of distributional justice and recognition, and controlled from top-down, when the Jewish majority in the Ministry of Education determines and decides for the Palestinian Arab minority in Israel the learning contents, goals, and books, which are devoid of any relationship to the needs of the Arab student. This miserable situation, which began in the period of the military government over the Arabs and continues today, is one of the factors causing the Arab parents to remove their children from the public schools and enroll them in the bilingual private schools. The main argument in this research study is that the Arab parents' 'escape' into the bilingual education frameworks is a type of protest or objection to the di- 
scriminatory situation that has endured for years, when there are no signs of hope for change, although there are young principals, teachers, and parents.

Dovrin $^{62}$ maintains that the experience of the educated parents, their familiarity with the educational system, and the threshold of expectations they set for the child provide many tools that are lacking for children who come from families that are not as well educated. The findings show that the educated parents' choice of a framework other than the regular Arab school was a good and correct decision, especially when their children began to learn in the institutions of higher education in Israel. Here it was possible to see that the formation of the personality was of great help, since these students were prominent in their personality and ability to cope with difficulties and challenges, unlike their parents' experience in the past. In addition, their mastery of the Hebrew language was also one of the main factors supporting their parents' argument about the importance of the Hebrew language in Israel.

The alternative school, the bilingual school, is considered by the Arab parents to be a positive and correct option, despite the dilemma and the warnings they received at the beginning about the registration of their children to the bilingual school: that this would ruin their social personality and their national identity. The Arab parents asserted that fortunately the outcome was the opposite from the 'dilemma and the warnings' they encountered in the beginning, and they are very satisfied with the educational, personal, and identity activity of their children.

\section{BIBLIOGRAPHY}

Abu Asba K., The Dropping out of Students in the Arab Educational System in Israel: Description of the Situation and Suggestions for Treatment, 1999. (Hebrew)

Abu Asba K., Attitudes of Different Factors in Arab Society on the Question of an Alternative Structure for the Arab Educational System in Israel: Summative Report, Israel: Follow-up after Issues of Arab Education in Israel, Institute for Research, Planning, and Educational Counseling, Gat: Masser 2003. (Hebrew)

Abu Asba K., Between Tolerance and Threat, Facets: Journal for Culture, Society, and Education, 2004, 29. (Hebrew)

Abu Asba K., The School Principal Is Subject to Great Pressures on the Part of the Clans, Another Country, 2005. (Hebrew)

Abu Asba K., Arab Education in Israel: Dilemmas of a National Minority, 2007. (Hebrew)

Abu Saad I., Multicultural Education and the Palestinian Arab Minority in Israel: The Issue of Bedouin Arab Education in the Negev, [In:] Education in a Multicultural Society: Pluralism and Points of Encounter between Social Rifts, Ed. P. Pery, Carmel, Jerusalem 2007, p. 125142. (Hebrew)

${ }^{62}$ N. Dovrin, Equality of Opportunities in Education and Demographic and Socioeconomic Barriers, 2015. (Hebrew) 
Adiv U., Mor O., Azaiza F., Hertz-Lazarovitz R., National Perception, Shared Activity, and Bilingual Education: The Case of the Galil School, Discovery: Multidisciplinary Journal for Education, Society, and Culture, 2013, January. (Hebrew)

Agbaria A.K., Jabareen Y., Policy of Training Arab Teachers in Israel in the Mirror of the Right to Education: Issues of Governance as an Expression of Recognition of the National-Cultural Uniqueness, Pages - Journal for Study and Research in Education, 2015, Mofet Institute. (Hebrew)

Al-Haj M., Trouble of Employment among Arab Academics in Israel, [In:] Arab Academics in Israel: Main Characteristics, Potential of Graduates, and Situation, Ed. M. Al-Haj, The Jewish-Arab Center, Haifa University, 1988. (Hebrew)

Al-Haj M., Arab Educational System in Israel: Issues and Trends, Floresheimer Institute for Policy Researches, Jerusalem 1994. (Hebrew)

Al-Haj M., Education, Empowerment, and Control: The Case of the Arabs in Israel, State University of New York Press, Albany, New York 1995.

Al-Haj M., Education among the Arabs in Israel: Control and Social Change, Magnes Press, Jerusalem 1996. (Hebrew)

Al-Haj M., Multiculturalism in Deeply Divided Societies: The Israeli case, International Journal of Intercultural Relations, 2002, 26(2), April.

Amara M., The Model of Bilingualism of Hand In Hand, The Center for Jewish Arab Education in Israel, 2005. (Hebrew)

Amara M., Saban I., The Status of the Arabic Language in Israel: Law, Reality, and Boundaries of Use in Law to Change the Reality, State and Society, 2004, 4. (Hebrew)

Anderson J. (Ed.), The Rise of the Modern State, Brighton 1986.

Aspachs-Bracons O., Clots-Figueras I., Costa-Font J., Masella P., Compulsory Language Educational Policies and Identity Formation, Journal of the European Economic Association, $2008,6,2-3$.

Avnon D., The Non-Democratic Aspect of the Basic Laws on the Topics of the Rights of Man, Politics, 1998, 2. (Hebrew)

Babiya I., The Ethnic Transfer in Palestine, Institute for the Study of Palestinianism, Beirut 2007. (Arabic)

Baker C., European Models of Bilingual Education, 1993.

Barak A., The Values of the State of Israel as a Jewish and Democratic State, Multidisciplinary Thinking in Humanistic Education, 2011, 6. (Hebrew)

Bargouti S., Israeli Educational Core Requires Fair Inclusion of the Arab Public, Multidisciplinary Thought in Humanistic Education, 2011, 6. (Hebrew)

Barnea S., Israeliness - Nationalism or Citizenship? Crisis and Anomaly in the Arab-Israeli Identity, [In:] New Directions: Journal for Issues of Zionism, Judaism, Policy, Society, and Culture, Ed. E. Ayal, 2011, 24, June. (Hebrew)

Bar-Tal D., Shared Beliefs in a Society: Social Psychological Analysis, Sage, London 2000.

Bekerman Z., Shhadi N., Palestinian Jewish Bilingual Education in Israel: Its Influence on School Students, Journal of Multilingual and Multicultural Development, 2003, 24(6).

Ben Shemesh Y., Individuality and Post-Nationalism in the Kadan Affair: Response to Yosef Gavrian, Acts of Law, 2010, 3. (Hebrew)

Bruner J., Peled Y., Rawls on Respect and Self-Respect: An Israeli Perspective, Political Studies, 1996, 44(2), June.

Crawford J., Best Evidence: Research Foundations of the Bilingual Education Act, National Clearinghouse for Bilingual Education, Washington DC: 1997.

Dovrin N., Equality of Opportunities in Education and Demographic and Socioeconomic Barriers, 2015. (Hebrew) 
Ghanem A., Levin-Rosales M., Game of Identities: The Construction of Identity among Palestinian Women Citizens of Israel Who Studied in Schools in the Jewish Sector, Trends, 2015, 51, May. (Hebrew)

Ghanem A., Mustafa M., The Palestinians in Israel - The Policy of the Minority in the Ethnic State, Medar - The Palestinian Center for the Study of Israeliness, 2009. (Arabic)

Golan-Agnon D., Why Are the Arab Students in Israel Discriminated Against? [In:] Inequality in Education, Ed. D. Golan-Agnon, Babel, Tel Aviv 2004. (Hebrew)

Hand In Hand Association Website (n.d.). http:/ / www.handinhandk12.org/

Hatav N., The Future Orientation of Youths in Arab Society in Israel: Characteristics and Factors, M.A. Thesis, The Open University, Jerusalem 1988. (Hebrew)

Jabareen Y., Law and Education: Critical Perspectives on Arab Education in Israel, American Behavioral Scientist, 2006, 49(8).

Jabareen Y., On the Constitutional Status of the Arab Minority in Israel: New Motion, State and Society, 2010, 7 (1). (Hebrew)

Jabareen Y., Agbaria A.K., Education on Hold; Government Policy and Civil Initiatives for the Promotion of Arab Education in Israel, Haifa University, The Faculty of Law, Drasat: Arab Center for Law and Policy, 2010. (Hebrew)

Jabareen Y., Agbaria A., Autonomy for Arab Education in Israel. Rights and Possibilities, Knowledge Discovery, 2014, 5, Spring. (Hebrew)

Jamal A., On the Patterns of the Establishment of the National Inequality in Israel, 2004. (Hebrew)

Kelman H.C., Group Processes in the Resolution of International Conflicts: Experiences from the Israeli-Palestinian Case, American Psychologist, 1997, 52.

Koren H., The Identity as Awareness: The Palestinians and the Arab Citizens of Israel - Between Unity and Uniqueness, National Security, 2009, 7, August. (Hebrew)

Landau Y., The Arab Minority in Israel, 1967-1991, Levi Eshkol Institute, The Hebrew University, Am Oved 1993. (Hebrew)

Mari S., Arab Education in Israel, Syracuse University Press, New York Press, Boulder, Syracuse 1978.

Mor-Sommerfeld A., Azaiza F., Hertz-Lazarowitz R., Into the Future: Towards Bilingual Education in Israel, Education, Citizenship, and Social Justice, 2007, 2(1).

Noyberger B., Minorities and Democracy, [In:] Knowledge, Society, and Regime, Ministry of Education, Culture, and Sport, Service of Publications, Jerusalem 1995. (Hebrew)

Pinson H., Anon D. (Eds.), Citizenship, Civil Society, and Education: The Israeli Case in the Mirror of Western Democracies, [In:] The Language of the Citizen in Israel, The Hebrew University of Jerusalem, Jerusalem 2006. (Hebrew)

Rabin Y., The Right to Education, Li-On Sarigim, Nebo 2002. (Hebrew)

Saban I., The Collective Rights of the Palestinian Arab Minority: What There Is, What There Isn't, and the Taboo, Studies in Law, 2002, 26, 1. (Hebrew)

Shwade U., Shavit Y., Delasha M. Ofek M., Integration of Arabs and Jews in the School in Israel, [In:] Report of the Situation of the State - Society, Economy, and Policy, Ed. D. Ben David, Taub Center for the Research of Social Policy in Israel, 2014. (Hebrew)

Smooha S., Measures of Jewish-Arab Relations in Israel, Haifa University, 2004. (Hebrew)

Tzartzur S., Arab Education in the Jewish State, 1981. (Hebrew)

Zilbersheid U., The Legal-Political Development of the Declaration of Independence - Victory of the Perception of Bourgeoisie Democracy, Democratic Culture, 2009, 12, 7. (Hebrew) 
